\title{
Aquaponic System with White Shrimp Litopenaeus vannamei Rearing and Production of the Plants Batis maritima, Sarcocornia neei and Sporobolus virginicus
}

\author{
Roberta Moriconi Freire Schardong ${ }^{1 *}$ \\ https://orcid.org/0000-0002-5115-2050 \\ Marcelo Freire Moro ${ }^{1}$ \\ https://orcid.org/0000-0003-4527-346X
}

Oriel Herrera Bonilla ${ }^{2}$

https://orcid.org/0000-0002-9140-6086

${ }^{1}$ Federal University of Ceará (LABOMAR/UFC), Tropical Marine Sciences, Fortaleza, Ceará, Brazil; ²Ceará State University, Biological Sciences Course, Fortaleza, Ceará, Brazil.

Received: 2019.09.02; Accepted: 2020.02.07.

*Correspondence: mfs.roberta@gmail.com, Tel.: +55-75-999955481 (R.M.F.S)

\section{HIGHLIGHTS}

- Shrimps and halophytes in aquaponic system.

\begin{abstract}
Aquaponics is a system that integrates aquaculture with plant production in which two species are benefited, and there is water saving. In this study was carried out with an aquaponic system to verify the interaction between the growth of the halophytes Batis maritime, Sarcocornia neei, and Sporobolus virginicus associated with white shrimp Litopenaeus vannamei rearing. We also investigated if there were different responses of physicochemical variables of the water in the experimental shrimp culture ponds integrated into the growth of plants and control ponds, without plants, throughout a 56-day period. The treatment experiment and control presented a statistically significant difference in total dissolved solids, salinity, total suspended solids, ammonia, orthophosphate, and nitrite. In the experimental treatment, with the presence of plants and recirculating water, a reduction of total suspended solids, ammonia and orthophosphate was observed. The rate of shrimp production was not significantly different between treatments, and the performance was similar to that of other studies. The biomass gain of the halophyte $B$. maritima was 876.6 grams in $0.5 \mathrm{~m}^{2}$ and of $S$. neei was 48.8 grams in $0.16 \mathrm{~m}^{2}$. All plants of the species $S$. virginicus died during the experiment.
\end{abstract}

Keywords: wasterwater; halophytic; effluent recirculation.

\section{INTRODUCTION}

Aquaculture is an economic activity that has grown globally and particularly in the Northeast of Brazil, where its development has been favored by edaphoclimatic conditions. This practice provides economic gains for producers and is a source of protein to feed the world's population, but it also has negative environmental challenges and generates waste that can cause environmental challenges [1]. A possible solution is the treatment of aquaculture effluents with plants that have bioremediation capacity and are potentially tradable, reducing the harmful effects of aquaculture [2]. 
Models of sustainable food production that integrate plant growing and culture of aquatic animals are known as aquaponic systems [3]. Aquaponics is considered a productive system that optimizes the use of water resources [4].

In an experiment with the halophyte Salicornia neei Lag. (reported in other studies Salicornia ambigua, Salicornia fruticosa or Salicornia gaudichaudiana [2,5,6]growing in an aquaponic system with culture of white shrimp Litopenaeus vannamei (Boone, 1931), confirmed the removal of excess nitrogen from the water, with the possibility of reuse of water and promising results in the production of green biomass [2].

Halophytes are salt-tolerant plants [5] with special physiological characteristics that provide adaptation to saline environments and can be used for different types of applications and maximizing economic benefits [5]. They can serve as a complementary source of nutrients for animals [6]; functional and medicinal food[7,8], provide the raw material for the production of green salt, rich in depurative and diuretic substances[9]; generate biomass for biodiesel production [10,11]; among other benefits.

Productive cultivation of halophytes in biological filters can be compromised by the influence of environmental factors [5]. Salt concentration and nutrient content in the effluent may surpass the absorption capacity of the roots or even become toxic to the plants depending on the characteristics of their roots and the physiological peculiarities of each species [5]. Knowledge of the interaction between physicochemical characteristics of the medium where halophyte species and the shrimp Litopenaeus vannamei are produced is necessary for the sustainable economic functioning of aquaponic systems [12] and food safety [13].

Thus, the purpose of the present study was to compare the physicochemical variables of the water from Litopenaeus vannamei shrimp ponds integrated to production of the halophyte Batis maritime L., Salicornia neei and Sporobolus virginicus (L.) Kunth, versus control ponds without plant cultivation, in a 56-day laboratory experiment. The zootechnical performance of shrimps and the biomass production of the plant species were also evaluated.

\section{MATERIAL AND METHODS}

\section{Experimental setting}

The experiment was carried out at the Laboratory of Nutrition of Aquatic Organisms (LANOA) of the Center for Coastal Aquaculture Studies (CEAC) of the Institute of Marine Sciences (LABOMAR) of the Federal University of Ceará.

The experiment was started on September 26 and concluded on November 21, 2017, lasting 56 days throughout eight weeks.

\section{Experimental design and implementation}

The experimental design (Figure 1(a), 1(b)) included control and experimental treatment, each with four replicates arranged through systematic intercalation [14]. Each control consisted of a shrimp culture pond with maximum water storage capacity of 61 liters, a feeding tray, and the aeration system. In the experimental treatment, a submerged pump connected by a hose to a PVC pipe structure was added to the pond to grow the plants. The pump flow rate for recirculation of water was 3 liters per minute and was continuously working throughout the experiment only in the experimental treatment.

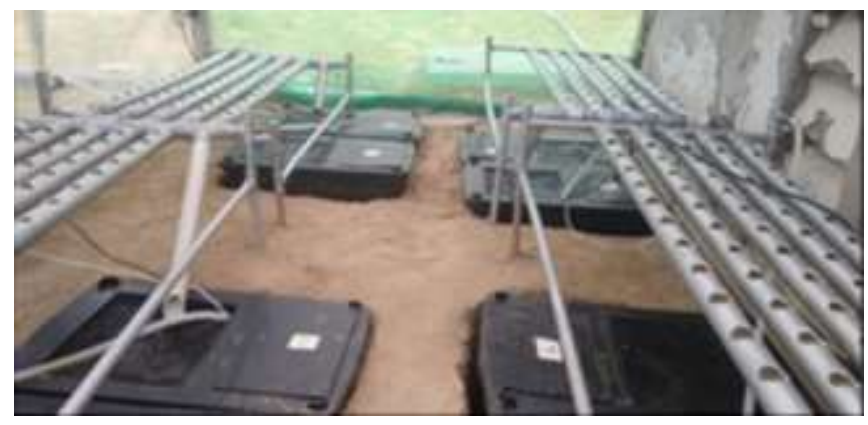

(a)

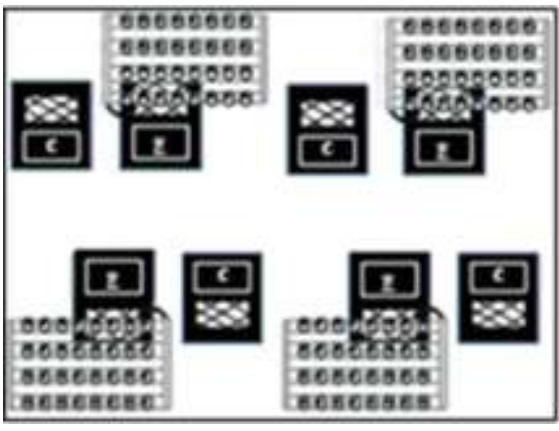

(b)

Figure 1. Photo (a) and scheme (b) of the control units - C and experimental units - E. 
Each of the four control and four experimental ponds was filled with 59 liters of water from nurseries of L. vannamei post-larvae of experimental ponds in the LANOA. When the shrimp reached an average weight of 1.5 grams, the eight ponds received 15 individuals $\left(15 \mathrm{shrimps} / \mathrm{m}^{3}\right)$ each, and the experiment was started.

The water in the ponds during the experiment was not renewed, but weekly losses were replaced with water from the Pacoti river, stored in a water reservoir of 1000 liters capacity installed at the side of the experiment site. Weekly the pond with the largest loss of water served as reference for the replacement of water in all ponds to maintain them at the same volume. To do this, the difference between this reference value and the water volume of the other seven ponds was removed from them, and the same amount of water was added until each pond had a volume of 59 liters again.

\section{Water: sampling and analytical methods}

During the experiment, the nitrogen, phosphorus, and solids series of each of the experimental and control ponds were monitored on a weekly basis. Water samples were collected weekly before and after water replenishment, and the concentration of non-ionized ammonia $\left(\mathrm{N}-\mathrm{NH}_{3}\right)$, dissolved nitrite $\left(\mathrm{N}-\mathrm{NO}_{2}{ }^{-}\right)$, dissolved nitrate $\left(\mathrm{N}-\mathrm{NO}_{3}{ }^{-}\right)$, dissolved orthophosphate $\left(\mathrm{P}-\mathrm{PO}_{4}{ }^{3-}\right)$, and total suspended solids (TSS) were determined in $\mathrm{mg.l}^{-1}$ using the photometric method (Method 8006, access (www.hach.com/assetget.download-en.jsa?id=7639983904)with commercial Hach-Lange tests using a spectrophotometer (DR 2800 Spectrophotometer, Hach Company, Loveland, USA).

Temperature, salinity and $\mathrm{pH}$ were measured directly on the ponds on a daily basis with a portable multiparameter ( $\mathrm{pH} / \mathrm{EC} / \mathrm{DO})$ meter (HI98194, Hanna), and dissolved oxygen was measured with an oximeter (AT 155, Alfakit).

\section{Halophytes: cultivation and data collection}

Three species of halophytes, Batis maritima, Saliornia neei, and Sporobolus virginicus, were selected for growing in the four experimental treatment units.

The rooted seedlings were arranged in the structures for culture in the aquaponic system, as shown in Figure 2a. Each structure received 30 seedlings of $B$. maritima, 10 seedlings of $S$. neei and 10 seedlings of $S$. virginicus (Figure $2 \mathrm{~b}$ ). The roots of the plants were submitted to a continuous flow of recirculating water from the shrimp ponds, a method known as Nutrient Film Technique (NFT).

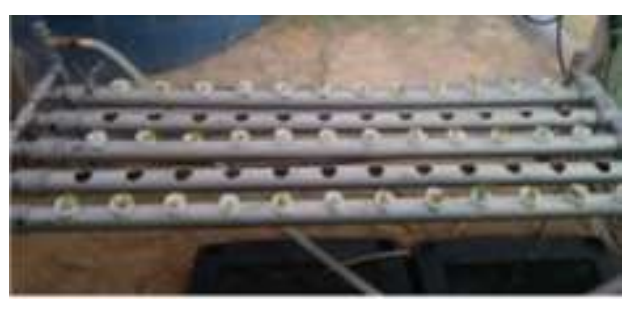

(a)

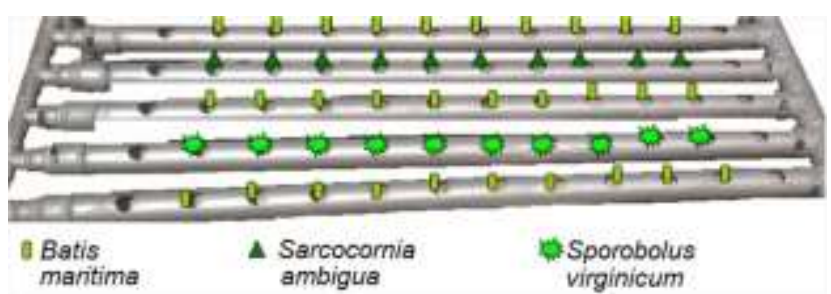

(b)

Figure 2. Structure of halophyte culture.

The height from the stem base to the upper end of each plant was measured once a week. The plants fresh biomass weighted at the beginning and at the end of the experiment.

\section{Shrimp: culture and data collection}

The shrimps were fed twice a day, at $8 \mathrm{~h}$ and $16 \mathrm{~h}$, with commercial feed containing $35 \%$ of crude protein offered in trays. The leftovers were removed from the trays, counted and weighed the next day, when a new portion of feed was to be offered.

Each shrimp was weighed individually at the beginning and at the end of the experiment. At the harvest, the number of shrimps and the final mass of each shrimp that had survived in each pond were recorded.

\section{Statistical analysis}

The statistical analysis included descriptive metrics, measures of dispersion, normality, homogeneity, hypothesis tests, and multivariate analysis, all performed in the software R (RStudio version 3.5.1, Boston, USA). The normality of each variable was checked with the Shapiro-Wilk Test and the homogeneity of variances with the Levene's test. 
Repeated measures ANOVA was used to evaluate if there was a significant difference between the physicochemical variables of the control and experimental treatments over time. Mixed models were used when the data did not meet the assumptions of normality and homogeneity of variances. Ammonia values that exceeded the detection range of the analytical tests $(>5)$ were standardized, adopting the value six.

The maximum $p$ acceptable for significance was 0.05 .

A principal component analysis (PCA) was applied to verify if the physicochemical variables were associated and if there was a pattern of clustering between the replicates of the experimental and control ponds.

The raw data generated by this job, additional information and analyze code are available at https://doi.org/10.6084/m9.figshare.7197911.

\section{RESULTS}

\section{Physicochemical variables of water}

There was statistically significant interaction in the ANOVA between treatments and weeks for the variables salinity, total dissolved solids (TDS), dissolved orthophosphate $\left(\mathrm{P}_{-} \mathrm{PO}_{4}{ }^{3-}\right)$, total suspended solids (TSS), non-ionized ammonia $\left(\mathrm{N}_{-} \mathrm{NH}_{3}\right)$ and $\mathrm{pH}$. There were higher values for salinity (Figure $3 a$ and TDS

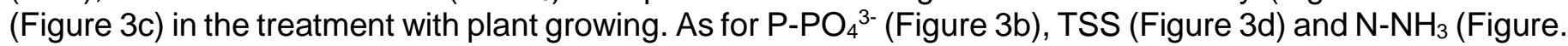
$3 e)$, the values were higher in control than in the experimental treatment.

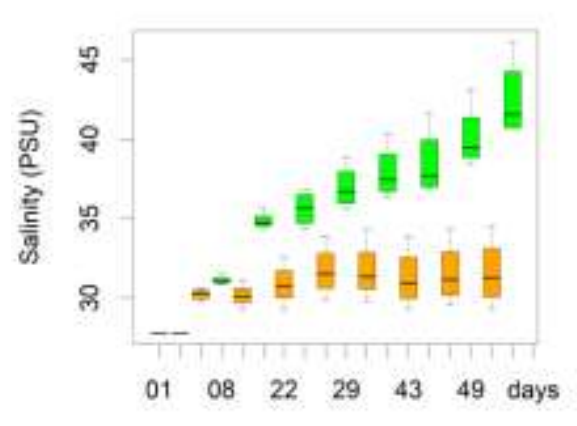

(a)

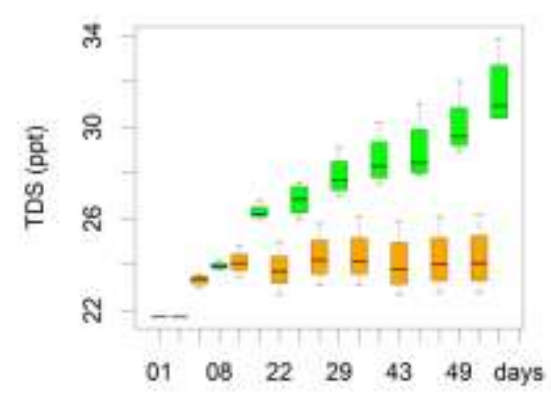

(c)

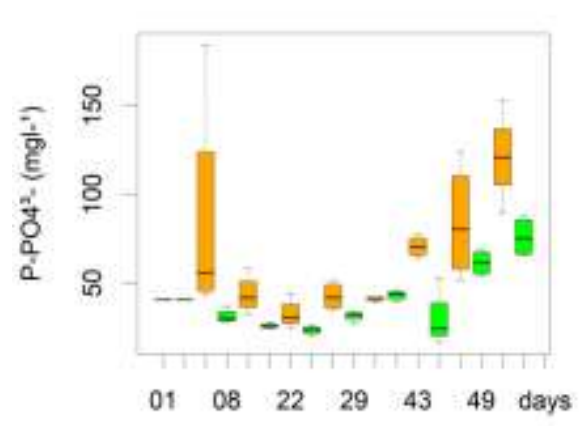

(b)

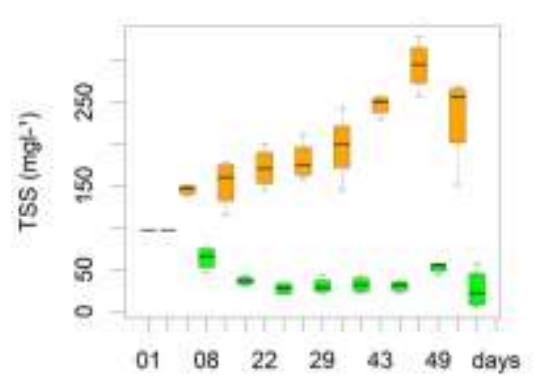

(d) 


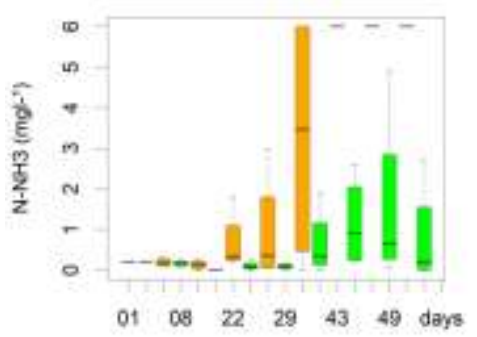

(e)

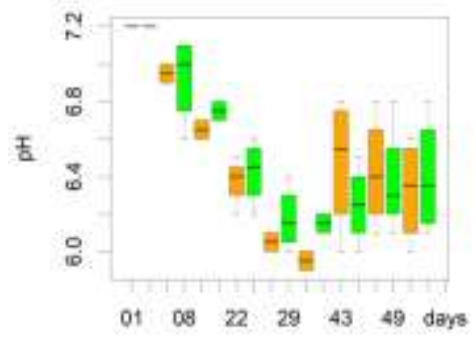

(f)

$$
\begin{aligned}
& \text { 믄ontrol } \\
& \text { ․ Experimental }
\end{aligned}
$$

Figure 3. Boxplot of the control $(n=4)$ and experimental $(n=4)$ treatment during 56 days of: (a) salinity; (b) P-PO43-; (c) TDS; (d) TSS; (e) N-NH3; (f) pH.

No significant differences were found between the control and experimental treatment for the variables temperature (Figure 4a), dissolved oxygen (Figure $4 \mathrm{~b}$ ), dissolved nitrate $\left(\mathrm{N}_{-} \mathrm{NO}_{3}{ }^{-}\right.$, Figure $4 \mathrm{c}$ ), and dissolved nitrite $\left(\mathrm{N}_{-} \mathrm{NO}_{2}{ }^{-}\right.$, Figure. $\left.4 \mathrm{~d}\right)$. However, significant differences were observed in the repeated measures ANOVA along the time for temperature, dissolved oxygen, and $\mathrm{N}-\mathrm{NO}_{3} \cdot$

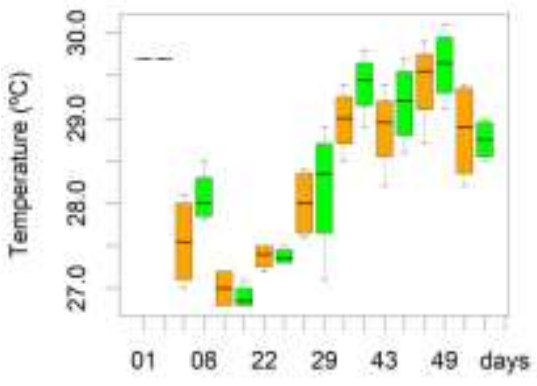

(a)

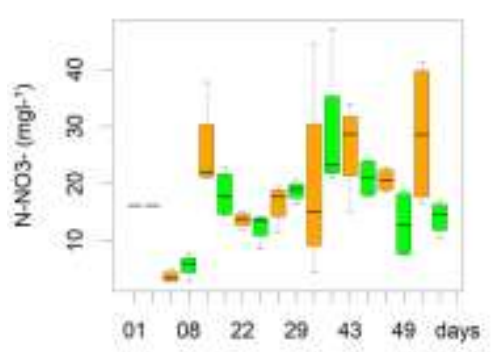

(c)

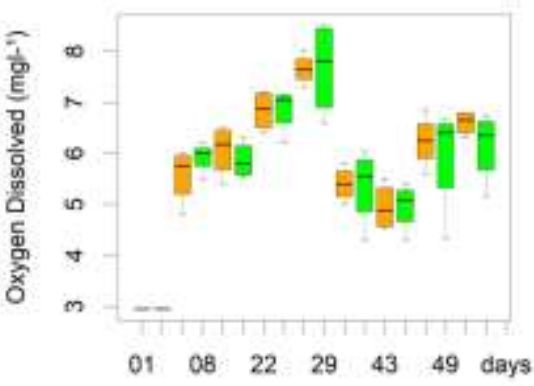

(b)

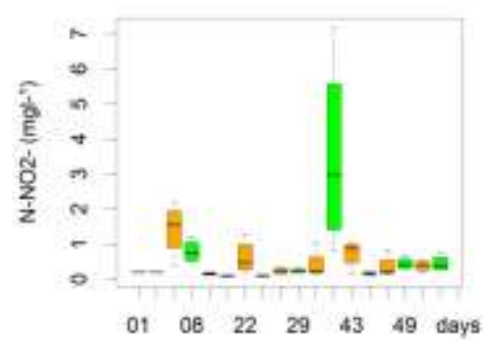

(d)

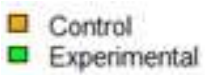

Figure 4. Boxplot of the control $(n=4)$ and experimental $(n=4)$ treatment during 56 days of: (a) temperature; (b) dissolved oxygen; (c) N-NO3-; (d) N-NO2-. 
As for the nitrogen series data, the $\mathrm{N}^{-\mathrm{NO}_{2}}{ }^{-}$values in the last four weeks were higher in the experimental

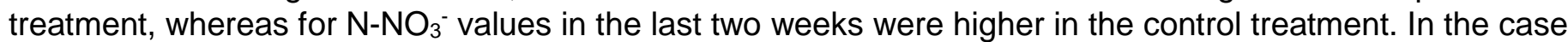
of $\mathrm{N}-\mathrm{NH}_{3}$, the differences increased significantly over time.

At the beginning of the second week, day 8 (Figure 5a), the salinity and TDS values, followed by $\mathrm{N}^{-\mathrm{NO}_{3}}$, were more positively related to each other and negatively associated with TSS in the principal component one of the PCA. The PC1 explained $43 \%$ of the joint variance of the physicochemical variables, while PC2 explained $25 \%$. The replicates of the experimental treatment were more positively related to the PC1, while the replicates of the control treatment were in the opposite side.

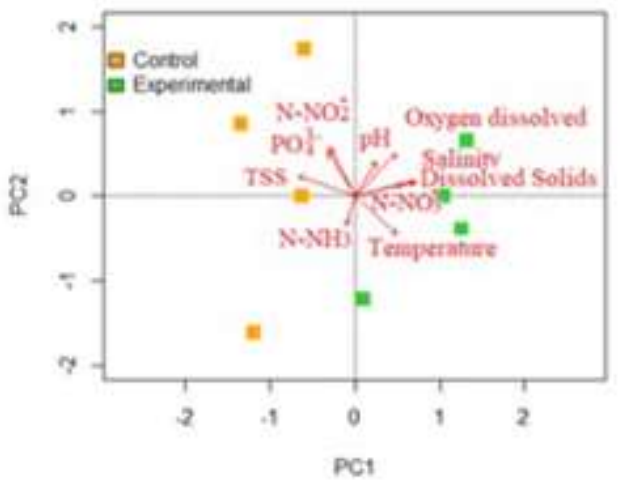

(a)

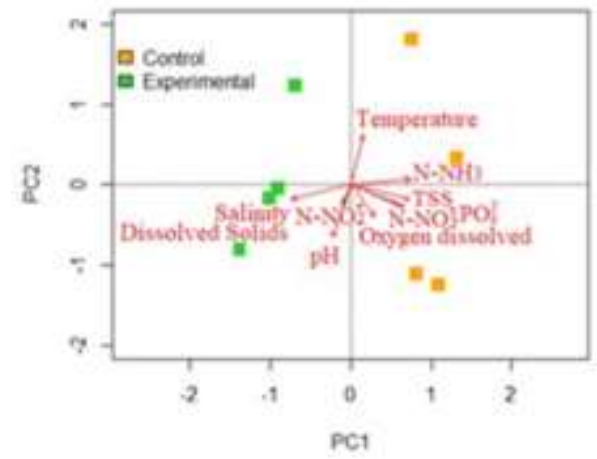

(b)

Figure 5. Biplot of the first (PC1) and second (PC2) PCA axis showing the clustering of replicates of the control and experimental treatment in relation to the physicochemical variables: (a) $2^{\text {nd }}$ week, $8^{\text {th }}$ day; (b) $8^{\text {th }}$ week, $56^{\text {th }}$ day.

At the end of the experiment, at the $56^{\text {th }}$ day (Figure $5 b$ ), PC1 explained $52 \%$ and PC2, $20 \%$ of the joint variance of the data. In PC1, the explanatory variables were $\mathrm{N}-\mathrm{NH}_{3}$, TSS, followed by $\mathrm{P}-\mathrm{PO}_{4}{ }^{3-}$ and $\mathrm{N}-\mathrm{NO}_{3}{ }^{-}$ which were positively related to each other and negatively related to salinity and TDS. The control replicates were clustered and close to the explanatory variables of this main component. In PC2, temperature and $\mathrm{pH}$ were opposed to each other, being the explanatory variables of this component and showing no clustering pattern of control and experimental ponds replicates.

The loss of water (Figure 6) in ponds with recirculating water of the experimental treatment was higher than in the control. A statistically significant effect for water loss (Figure 6) between the control and experimental treatment $(n=4 ; p=0.0000000859)$ was observed. Statistically significant differences in water loss between weeks $(n=4, p=0.0349)$ was seen in the control group but not in the experimental treatment $(n=4 ; p=0.0661)$.

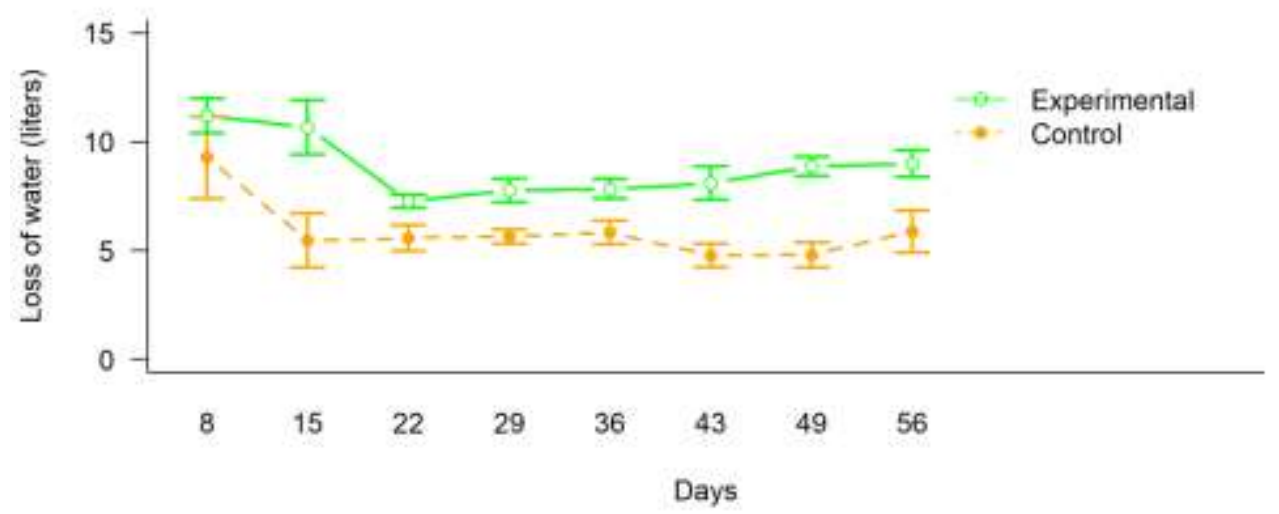

Figure 6. Line graph showing standard errors for the volume of weekly water lost in the control $(n=4)$ and experimental $(n=4)$ ponds. 


\section{Production of halophytes}

The growth in height of individual plants (Figure 7a) and the initial and final total biomass weight (Figure 7b) of the halophytes $B$. maritima and $S$. neei are shown in Figure 7 . The total biomass gain of the plants in the experimental treatment was $876.63 \mathrm{~g}$ for $B$. maritima and $48.8 \mathrm{~g}$ for S.neei.

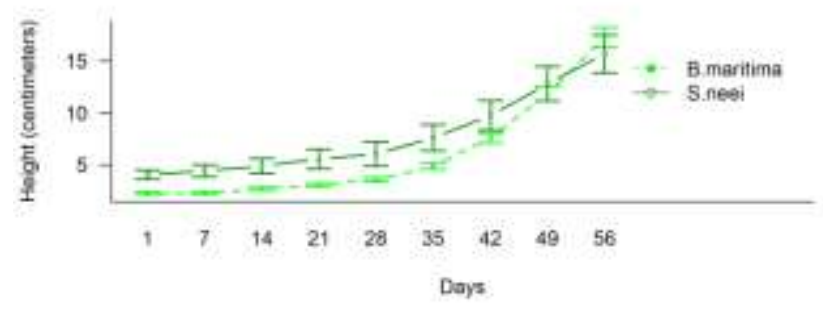

(a)

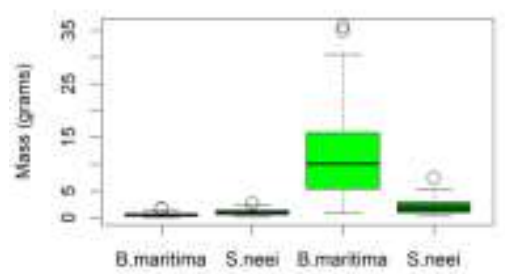

(b)

Figure 7. Graphics of the experimental treatment $(n=4)$ : (a) Line graph of showing standard deviations for the height growth; (b) boxplot of the initial and final mass of $B$. maritima and $S$. neei plants.

Initially plants of $S$. virginicus developed roots but tillers dried out until the end of the experiment. The average plant densities per bench and survival rate percentages of $B$. maritima $(21.0 \pm 4.8$ plants; $70.0 \%)$ were higher than observed for S. neei (5.5 \pm 3.2 plants; $52.5 \%)$.

\section{Production index of Litopenaeus vannamei}

There was no statistically significant difference in weight between the two treatments, neither at the beginning nor at the end of the experiment.

Survival, initial and final biomass the shrimps, in experimental treatment and control, no significant differences were found. The shrimp production indices of the control and experimental treatment are presented in Table 1.

Table 1. Shrimp (L. vannamei) performance in a control without aquaponic system and aquacopic system for 56 days with 254 shrimps $\mathrm{m}^{-3}$.

\begin{tabular}{lll}
\hline \multicolumn{1}{c}{ Parameter } & \multicolumn{1}{c}{ Control } & Experimental \\
\hline Final average weight $(\mathrm{g}) \pm \mathrm{SD}(\min -\mathrm{max})$ & $12.9 \pm 4.1(7.7-18.3)$ & $11.5 \pm 2.9(8.0-14.3)$ \\
Weekly weight gain $\left(\mathrm{g} \cdot\right.$ weekly $\left.^{-1}\right)$ & 1.5 & 1.3 \\
Final biomass $\left(\mathrm{g}^{-3}\right)$ & 3103.2 & 2866.7 \\
Survival rate $(\%)$ & 91.7 & 95.0 \\
Feed conversion factor & 1.4 & 1.5 \\
Biomass gain $(\mathrm{g})$ & 158.1 & 142.6 \\
\hline
\end{tabular}

Temperature [15] (Figure 8a), salinity [16] (Figure 8b), N-NO ${ }^{-}$[19] (Figure 9c), and TSS [17] (Figure 9d) were within the recommended ranges (dashed red line) for shrimp culture. In the case of $\mathrm{pH}$ [17] (Figure 8c), dissolved oxygen [15] (Figure 8d), and $\mathrm{N}-\mathrm{NO}_{2}$ [18] (Figure 9b), conditions were adequate in most of the measurements. 


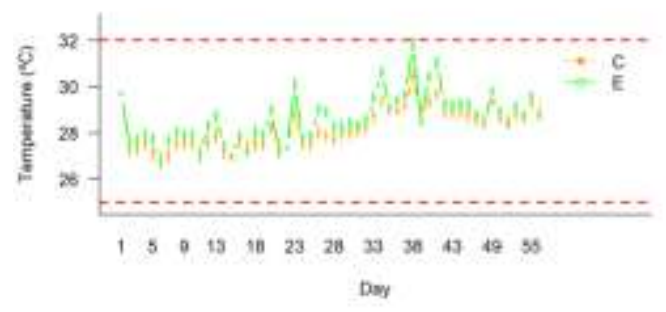

(a)

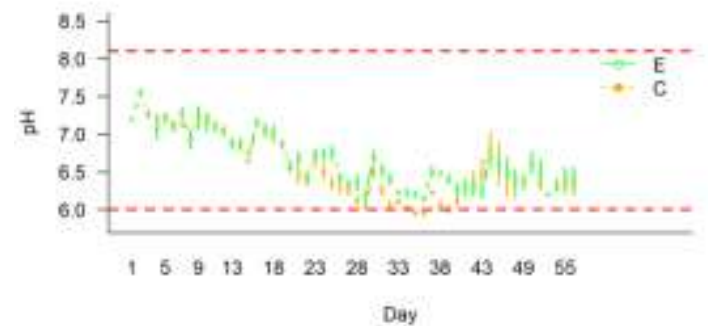

(c)

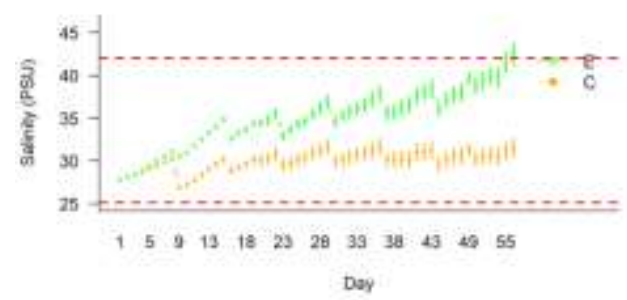

(b)

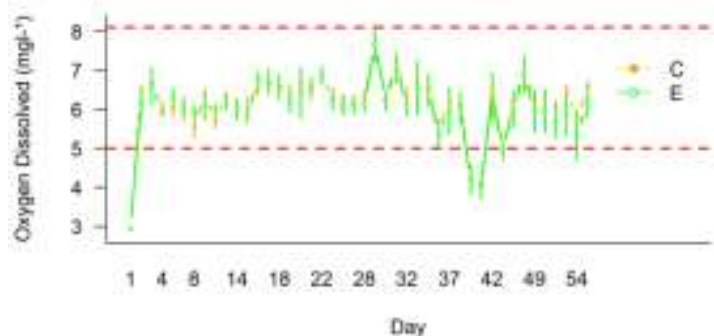

(d)

Figure 8. Daily average values of the control - $C(n=4)$ and experimental - $E(n=4)$ treatment of: (a) temperature; (b) salinity;(c) pH; (d) dissolved oxygen. Recommended values for shrimp culture are shown in the dashed red line.

For $\mathrm{N}^{-\mathrm{NH}_{3}}$ (Figure 9A) [15], the values exceeded the range of appropriate values for the shrimps. In the case of $\mathrm{P}_{-} \mathrm{PO}_{4}{ }^{3-}[16]$, the values were above the recommended values for shrimp culture.

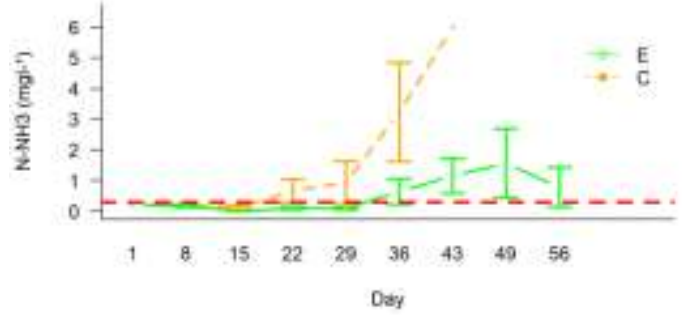

(a)

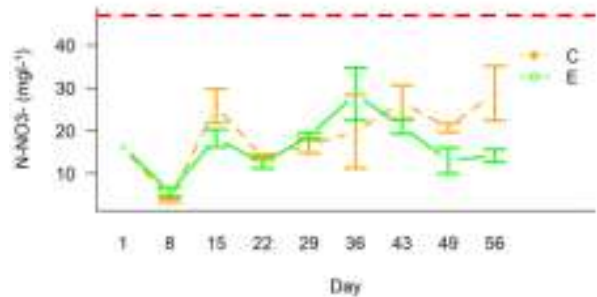

(c)

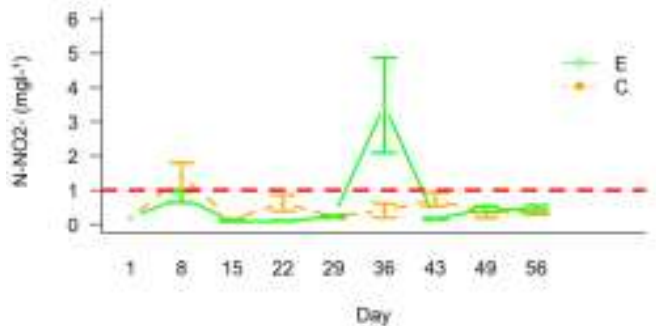

(b)

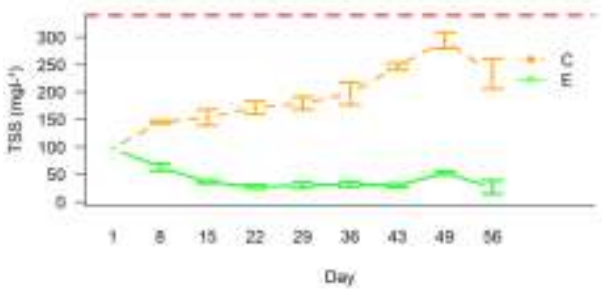

(d)

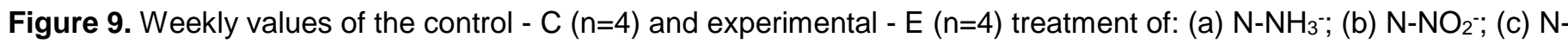
$\mathrm{NO}_{3}$; (d) TSS. Recommended values for shrimp culture are shown in the dashed red line. 


\section{DISCUSSION}

The experimental treatment with plant growing promoted the removal of $\mathrm{N}-\mathrm{NH}_{3}{ }^{-}, \mathrm{P}_{-} \mathrm{PO}_{4}{ }^{3-}$, and TSS from the circulating water. The halophyte $B$. maritima obtained higher biomass gain than $S$. neei, while Sporobolus virginicus did not adapt to the experiment, and all plants of this species died. The zootechnical performance of the shrimp was not affected by the presence of plants, revealing results similar to those of former studies.

\section{Physicochemical variables}

Water circulation and flow through the plants were the two conditions that differed between the experimental and the control treatment. Throughout the eight weeks, they led to statistically significant differences in physicochemical variables such as salinity and TDS, which were higher in the experimental treatment, and accumulation of TSS, with higher concentration of $\mathrm{N}-\mathrm{NH}_{3}{ }^{-}$and $\mathrm{P}-\mathrm{PO}_{4}{ }^{3-}$ in the control treatment.

Salinity, measured according to the total concentration of dissolved inorganic ions in water [19], is directly associated with TDS. These solids are measured according to all materials dissolved in the water, both organic and inorganic [20].

Results obtained in a study with wastewater fromthe plastic industry [21] showed that halophyte species were able to reduce TDS by $45 \%$ in comparison to the control treatment, where the soil had no plants. The same study compared the control treatment with another control with effluent, without soil or plants, confirming better performance in the experimental treatment with soil, due to its ability to reduce TDS by ion adsorption [21].

In the present study, TDS values were higher in the presence of growing plants. The two conditions that differed between the experimental and control treatment may have contributed togreater loss of waterthrough organic matter production and evapotranspiration of plants in the experimental ponds, causing a progressive accumulation of TDS and consequent increase of salinity [20].

Daily water loss in aquaponic systems is influenced mainly by the surface ratio of the hydroponic system, the culture pond, and the plants of the hydroponic section [22]. Other water losses have been reported as resulting from the physiological processes of the animals and their movement, and the evaporation and evapotranspiration of plants considered the most relevant factor in the determination of water loss in aquaponic systems [22]. Daily water losses of $9 \%, 15 \%$, and $41 \%$, weekly, were recorded in an aquaponic system with integrated growing of edible plants and fish rearing [23].

In the experimental treatment, although the recirculating water was inside closed PVC pipe structures, the water was poured back into the shrimp pond in a free fall of five centimeters of height, thus producing splashes. Plant evapotranspiration in the experimental treatment probably had a greater influence on water loss, indicated by the increase seen in the last weeks (Figure 6), coinciding with the plant's growth and increase of leaf area (Figure 7). An experiment with different species of edible plants grown in an aquaponic system indicated that the need for water replenishment was mainly due to the evapotranspiration of the plants [24].

The significantly lower values of total suspended solids in the experimental treatment are directly related to their retention in aquaponic structures and in the roots of plants [2]. Pinheiro and coauthors [2], in an experiment with an aquaponic system, the researchers promoted the circulation of water in hydroponic bench gutters with plants (experimental treatment) and without plants (control) using decantation chambers to keep the concentration of TSS under control in both treatments, returning the water to the tank from the bottom of the decantation chamber. They considered that there was retention of suspended solids, both in the decantation chambers and in the hydroponic benches, due to the reduced suspended solids in the water. The researchers concluded [2] that the reduction observed in the treatments was higher in the treatment with plants, possibly due to the retention of TSS in the root zone of the plants.

Figure $3 d$ shows that TSS values did not present increase in the weekly measurements in the experimental treatment. This was possibly due to the concomitant development of roots that allowed greater retention of TSS and, thus, canceled the cumulative action expected in the temporal trend line.

Lower $\mathrm{P}_{-} \mathrm{PO}_{4}{ }^{3-}$ values in the experimental than in the control treatment are also related to the removal of these compounds since they are frequently linked to TSS [25]. Organic matter accumulated in irrigation channels can be beneficial in aquaponic systems because the decomposition of solids promotes the mineralization process, causing the release of inorganic nutrients essential to plant growth [25]. However, high particulate OM may lead to high oxygen demand, decrease in redox potential and acidification, conditions that may be responsible for $\mathrm{S}$. virginicus failure to grow on the experimental hydroponic condition. In addition, plants need and absorb orthophosphate available in the medium for their growth [21].In the 
treatment of fishmanured water with the species Vetiveria zizanioides, there was a reduction of $42.75 \%$ in orthophosphate by the 14th day of the experiment.

At the end of the first week, TSS (Figure 3d) presented the first differences between the control and experimental treatment, while differences in $\mathrm{N}-\mathrm{NH}_{3}$ (Figure $3 \mathrm{e}$ ) and $\mathrm{P}_{-} \mathrm{PO}_{4}{ }^{3-}$ (Figure $3 \mathrm{~b}$ ) were seen from the sixth week, the 43th day, onwards. In the experiment by Pinheiro and coauthors [2], it was found that, from the 43th to 56th day, ammonia values were about $0.2 \mathrm{mg} \mathrm{l}^{-1}$ higher in the treatment with plant growing than in control.

A difference between the present experiment and the one conducted by Pinheiro and coauthors [2] was the recirculation of water in the two treatments, with and without plants, in hydroponic benches and through decantation chambers, causing TSS concentration to drop. The decrease in TSS concentration may cause a reduction of bacterial nitrifying biomass, causing a gradual accumulation of total ammonia [2,25].

In the nitrogen series, the behavior of $\mathrm{N}-\mathrm{NO}_{2}-$ differed between the control and experimental treatment from the 15th day onwards, and of the $\mathrm{N}-\mathrm{NO}_{3}{ }^{-}$from the $36^{\text {th }}$ day. The joint variation of this series indicates a possible action of nitrifying bacteria with nitrate production and its absorption by the plants in the experimental treatment. Plants play a fundamental role in the nitrogen absorption, avoiding nitrate accumulation in aquaponic systems [26].

The increase of $\mathrm{N}-\mathrm{NH}_{3}$ and $\mathrm{N}-\mathrm{NO}_{3}{ }^{-}$in the last weeks in the control treatment possibly occurred due to the accumulation of organic matter that interferes in metabolic pathways of bacteria and algae. Microbial communities in closed shrimp culture systems withoutthe management of solids tend to go through a reduction of algae and a dominant presence of bacteria [27]. An experiment witha super-intensive culture of shrimp concluded that the photosynthesis of microorganisms present in the water column was reduced by the increased levels of volatile suspended solids [26]. The suppression of the growth of algae by increasing turbidity and suspended solids causes accumulation of particles, greater biochemical oxygen demand, and suppression of growth of beneficial algae with the increase of potentially dangerous microorganisms [27].

The three groups that contribute to the detoxification of nitrogenous waste are: algae, which absorb ammonia, nitrite and nitrate during their growth; nitrifying bacteria, which oxidize ammonia, and produce nitrite and nitrate during chemosynthesis; and heterotrophic bacteria that require high concentrations of oxygen for assimilation of ammonia [27]. Nitrifying bacteria are slow to get established, leading to toxic ammonia and nitrite peaks [27]. The reduction of ammonia and nitrate observed in the experimental treatment was possibly caused by the action of these three groups of microorganisms.

The $\mathrm{pH}$ is the main factor that controls microbial activities and affects the availability of nitrogen to plants [25]. This occurs when values are below 6.4 or above 9.021 . These values were not seen in the present experiment.

\section{Production of halophytes}

Batis maritima was the halophyte that presented the higher survival rate and biomass production among the three cultivated species. Although $S$. virginicus is a true halophyte, it did not adapt to the growing structure and/or to the physicochemical conditions of the water and had no surviving specimens until the end of the study.

The dry biomass gain for native $B$. maritima irrigated with seawater (40 ppt) in a study conducted in Puerto Pênasco, Sonora, Mexico was of $1.7 \mathrm{~kg} \cdot \mathrm{m}^{2}$ per year [28]. In contrast, the wet mass value reached in the present study was of $1.8 \mathrm{~kg} \cdot \mathrm{m}^{2}$.

The production of fresh biomass by $S$. neei of $0.14 \mathrm{~kg} \mathrm{~m}^{-2}$ was lower than in other experiments that presented values of $8 \mathrm{~kg} \mathrm{~m}^{-2}$ in 73 days [2], and $6 \mathrm{~kg} \mathrm{~m}^{-2}$ and $2 \mathrm{~kg} \mathrm{~m}^{-2}$ in 150 days [2] possibly due to the high mortality rate. It is clear that the succulent Batis maritima was the best option for this growing system. This is very positive because Batis maritima is native to the region, and, being an edible succulent halophyte, it can serve as a source of food for the cattle. Ceara state in Brazil has many small farmers rearing shrimps as a source of income. This activity generates effluents that are usually disposed on the environment without any treatment. Our study suggests that creating a treatment system using native Batis maritima could improve effluent quality and generate food the cattle, possibly bringingthe support of these small landowners to establish decentralized treatment systems with these plants.

\section{Production index of Litopenaeus vannamei}

Temperature measurements were in the ideal range, $26.1^{\circ} \mathrm{C}-32.6^{\circ} \mathrm{C}$, near the optimum temperature, between $28^{\circ} \mathrm{C}$ and $32.0^{\circ} \mathrm{C}$ [15]. The ideal temperature range favors the metabolic rate of shrimp; it is directly 
related to feed and oxygen consumption, excretion of ammonia and better performance for growth [19]. No daily variation greater than $4{ }^{\circ} \mathrm{C}$ was observed in daily measurements, which causes stress for both shrimp and biofilter bacteria [19].

The production index for shrimp in this study presented similar results to those found in other studies $[2,29,30]$ (Table 2).

Table 2. Average final weight (g), final biomass $\left(\mathrm{kg} \mathrm{m}^{3}\right)$, means Feed Conversion Ratio (FCR), and survival (\%) of $L$. vannamei[2,29,30] ( ${ }^{\star}$ Experimental treatment with plants).

\begin{tabular}{llllll}
\hline & $\begin{array}{l}\text { Control or } \\
\text { Experiment }\end{array}$ & $\begin{array}{l}\text { Poli and } \\
\text { coauthors } \\
2019[29]\end{array}$ & $\begin{array}{l}\text { Arantes and } \\
\text { coauthors } \\
2017[30]\end{array}$ & $\begin{array}{l}\text { Pinheiro and } \\
\text { coauthors } \\
2017[2]\end{array}$ & This experiment \\
\hline Experiment duration(days) & & 57 & 61 & 73 & 56 \\
Desity (shrimp $\mathrm{m}^{-3}$ ) & & 312 & 164 & 250 & 254 \\
Final average weight(g) & Control & $14.1 \pm 0.1$ & $10.1 \pm 0.2$ & $11.6 \pm 0.3$ & $12.9 \pm 4.1$ \\
& Experiment & $14.6 \pm 0.2$ & $12.7 \pm 0.4$ & $11.7 \pm 0.5^{*}$ & $11.5 \pm 2.9^{*}$ \\
Final biomass $\left(\mathrm{kg} \mathrm{m}^{-3}\right.$ ) & Control & $3.1 \pm 0.45$ & $1.0 \pm 0.2$ & $1.5 \pm 0.3$ & 3.1 \\
& Experiment & $3.2 \pm 0.75$ & $1.6 \pm 0.0$ & $1.4 \pm 0.4^{*}$ & $2.9^{*}$ \\
FCR & Control & $1.7 \pm 0.05$ & $1.9 \pm 0.3$ & $2.2 \pm 0.1$ & 1.4 \\
Survival(\%) & Experiment & $1.7 \pm 0.05$ & $1.3 \pm 0.0$ & $2.1 \pm 0.1^{*}$ & $1.5^{*}$ \\
& Control & $89.3 \pm 1.2$ & $57.8 \pm 1.2$ & $74.5 \pm 2.1$ & 91.7 \\
& Experiment & $88.0 \pm 2.0$ & $73.8 \pm 1.4$ & $72.5 \pm 1.2^{*}$ & $95.0^{*}$ \\
\hline
\end{tabular}

\section{CONCLUSIONS}

The aquaponic system tested in this study improved the quality of the effluents of shrimp farming with reduction of total suspended solids, ammonia, and orthophosphate. The shrimp production index remained adequate when compared to other studies. The native succulent species Batis maritima had a higher survival rate among the three cultivated species and produced more biomass. It seems that this species is appropriate to be tested in larger treatment systems. Because it improves effluent quality and at the same time can be used as a source of food for the cattle, small shrimp producers would probably by simulated to apply this system to their farms. More over, saline, brackish waters are common in many places in the Brazilian semiarid, where we developed our study. This social use of this brackish water is difficult, and some farmers are using them to grow shrimps or nile tilapia in ponds. If they are presented to an effluent treatment system for these brackish water that provides succulentplants for their cattle, it is likely that this system can be of wides preadadoption.

Acknowledgments:The authors thank Professor Alberto Jorge Pinto Nunes and his team for the support in the development of the research at CEAC; the Claudio Warehouse and Vamberto Comercial for the donation of materials for the preparation of the equipment used in the experiment; and the Foundation for the Support of Scientific and Technological Development of Ceará (Funcap) for the provision of a PhD scholarship for research.

\section{REFERENCES}

1. Jegatheesan V, Shu L, Visvanathan C. Aquaculture effluent: impacts and remedies for protecting the environment and human health. In: Nriagu J, editor. Encyclopedia of environmental health, Elsevier Science, Burlington: Vt; 2011;123-35.

2. Pinheiro IC, Arantes R, Do Espírito Santo CM, Do Nascimento Vieira F, Lapa KR, Gonzaga LV, et al. Production of the halophyte Sarcocornia ambigua and Pacific white shrimp in an aquaponic system with biofloc technology. Ecol. Eng. 2017;100:261-7.

3. Diver S. Aquaponics - Integration of hydroponics with aquaculture. ATTRA Natl. Sustain. Agric. Inf. Serv. Natl. Cent. Appropr. Technol. [Internet]. 2006; IP163 [about 1 p.]. Available from: https://attra.ncat.org/attrapub/viewhtml.php?id=56 (accessed on Sep 24 2018).

4. Goddek S, Delaide BPL, Joyce A, WuertzS, Haissam JM, Amit G, et al. Nutrient mineralization and organic matter reduction performance of RAS-based sludge in sequential UASB-EGSB reactors. Aquacult. Eng. 2018;83:10-9.

5. Buhmann A, PapenbrockJ.Biofiltering of aquaculture effluents by halophytic plants: Basic principles, current uses and future perspectives. Environ. Exp. Bot.2013;92:122-33.

6. Shaer HMEL. Halophytes and salt-tolerant plants as potential forage for ruminants in the Near East region. Small Rumin. Res. 2010;91(1):3-12. 
7. Rhee MH, Park HJ, Cho JY. Salicornia herbacea: botanical, chemical and pharmacological review of halophyte marsh plant. J. Med.PlantsRes. 2009;3(8) 548-55.

8. KsouriR, KsouriWM, Jallail, DebezA, Magne C, Hiroko I, et al. Medicinal halophytes: potent source of health promoting biomolecules with medical, nitraceutical and food applications. Crit. Rev. Biotechnol. 2012;32(4):289326.

9. Raposo MFJ, MoraisRMSC,Morais AMMB. Controlled atmosphere storage for preservation Salicornia ramosissima. IJPTI.2009;1(4):394-404.

10. Abideen Z,AnsariR, Gul B, Khan MA. The place of halophytes in Pakistan's biofuel industry. Biofuels. 2012;3(2):211-20.

11. Gul B, Abideen Z, Ansari R, Khan MA. Halophytic biofuels revisted. Biofuels. 2013; 4(6): 575-77.

12. Castilho-Barro L, Almeida F, Henriques M, SeiffertW. Economic evaluation of the commercial production between Brazilian samphire and whiteleg shrimp in an aquaponics system. Aquacult. Int. 2018: 26(5): $1187-206$.

13. FAO. The future of food and agriculture - Trends and challenges. Rome: Food and Agriculture Organization of the United Nations; 2017.

14. Hurlbert SH. Pseudoreplication and the design of ecological field experiments. Ecol. Monogr. 1984; 54 (2): 187211.

15. Alves CS, Mello GL. [Manual for the hydrobiological monitoring in shrimp farms]. Recife: FAEPE/ SEBRAE - PE; 2007.

16. Alva MM, Gaxiola LMS, Alcalá HMG,editors. [Sanitary protocol for the cultivation of white shrimp (L. vannamei) in the state of Baja California, Mexico]. Comité Estatal de Sanidad e Inocuidad Acuícola de Baja California, A.C; 2007.

17. Krummenauer D, Samocha T, Poersch L, Lara G, Easielesky E. The Reuse of Water on the Culture of Pacific White Shrimp, Litopenaeus vannamei, in BFT System. J. World Aquacult. Soc.2014; 45(1): 3-14.

18. Boyd CE. Water Quality in Ponds for Aquaculture. Auburn, AL: Auburn University/Alabama Agricultural Experiment Station; 1984.

19. Van WykP, ScarpaJ. Water quality requirements and management. In: Van Wyk P, Davis-Hodgkins M, Laramore R, Min K, Mountain J, Scarpa J, editors. Farming marine shrimp in recirculating freshwater systems. Florida: Departament of Agriculture and Consumer Services, Tallahassee. 1999; 141-62.

20. Rooss JC, Pieterse AJH. Salinity and dissolved substances in the Vaal River at Balkfontein, South Africa. Hydrobiologia. 1995; 306: 41-51.

21. Saiyood S, Vangnai AS, Inthorn D, Thiravetyan P. Treatment of Total Dissolved Solids from Plastic Industrial Effluent by Halophytic Plants. Water, Air, Soil Pollut. 2012; 8(223): 4865-73

22. Maucieri C, Nicoletto C, Junge R, Schmautz Z, Sambo P, Borin M. Hydroponic systems and water management in aquaponics: A review. Ital. J.Agron. 2018; 13(1012): 1-11.

23. Graber A, JungeR. Aquaponic Systems: Nutrient recycling from fish wastewater by vegetable production. Desalination. 2009; 246: 147-56.

24. Hu Z, Lee JW, Chandran K, Kim S, Brotto AC, Khanal SK. Effect of plant species on nitrogen recovery in aquaponics. Bioresour. Technol.2015; 188: 92-8.

25. Wongkiew S, Popp BN, Kim HJ, Khanal KS. Fate of nitrogen in florating-raft aquaponic systems using natural abundance nitrogen isotopic compositions. Int. Biodeterior. Biodegrad. 2017; 125:24-32.

26. Vinatea L, Gálvez AO, Browdy CL, Stokes A, Venero J, Haveman J, et al. Photosynthesis, water respiration and growth performance of Litopenaeus vannamei in a super-intensive raceway culture with zero water exchange: Interaction of water quality variables. Aquacult. Eng. 2010; 42: $17-24$.

27. Ray AJ, Lewis BL, Browdy CL, Leffler JW. Suspended solids removal to improve shrimp (Litopenaeus vannamei) production and an evaluation of a plant-based feed in minimal-exchange, superintensive culture systems. Aquaculture. 2010; 299: 89-98.

28. O'Leary JW, Glenn EP, Watson MC. Agricultural production of halophytes irrigated with seawater. Plant Soil. 1985; 89(1-3): 311-321.

29. Poli AM, Legarda EC, Lorenzo MA, Pinheiro I, Martins MA, Seiffert WQ, Vieira FN. Integrated multitrophic aquaculture applied to shrimp rearing in a biofloc system. Aquacult. 2019; 511: 73427.

30. Arantes R, Schveitze R, Magnotti C, Lapa KR, Vinatea L. A comparison between water Exchange and settling tank as a method for suspended solids management in intensive biofloc technology systems: effects on shrimp (Litopenauesvannamei) performance quality and water use. Aquacult. Res.2017; 48:1478-90. 